\title{
Preface
}

In this book I set forth the conceptual framework for a new science of organizations. My objective is to contrast a multicentered model of social systems analysis and organizational design with the current marketcentered model which has dominated private enterprises and public agencies for the last eighty years. Generally I argue that a marketcentered theory of organizations is applicable not to all, but only to a special type of activity. Attempts to apply its principles to all forms of activity are hindering the actualization of possible new social systems needed to overcome the basic dilemmas of our society. I further contend that the model of manpower and resource allocation prescribed by this dominant organization theory is not mindful of ecological requirements and is therefore not commensurate with the potentialities of the contemporary state of productive capabilities. Finally, I suggest that the manner in which the dominant model is taught is deceptive and has disastrous consequences since the limits of its functional character are not acknowledged.

I am using the expression 'new science of organizations' in a broad sense. It includes not only matters pertinent to fields currently labelled as business and public administration, but also themes specifically pertinent to economics, political science, policy science, and to social science in general. Thus, as conceived in this book, the new science of organizations addresses itself to problems of ordering social and personal affairs in a micro as well as a macro perspective.

The socialization process is formally and informally organized in today's market-centered nations to make the human individual essentially sensitive to economic inducements. This condition is an episode of psychic deformation from the standpoint of the view of man pervading 


\section{$x$ Preface}

the argument of this book. To spell out this view is a self-defeating endeavor because any such attempt constitutes a closure upon the potential of human experience. The understanding of man, however, can be continuously drawn from the reading of deeds and texts where wisdom speaks to all human beings irrespective of their historical and racial circumstances. The new science of organizations is not concerned only with social systems required to enable individuals to succeed in a marketcentered society, but with issues and problems of social systems design common to all human societies.

By and large the teaching and training offered to students not only in schools of public administration and business, but in departments of social science as well, is still predicated on the assumptions of the marketcentered society. An alternative model of thought, not yet articulated in systematic terms, is needed today, because the market-centered society, more than two hundred years after its rise, is now disclosing its limitations and its distortive impingement upon human existence at large. It is no less than such a mode of thought that this book seeks to articulate.

In chapter 1 I deal with the root concept of all social science - reason. Modern social science cannot be adequately explained apart from the peculiar understanding of reason it implies. In this century the critique of modern reason was begun by Max Weber and Karl Mannheim who nevertheless failed to face consistently its complexity. More recently Eric Voegelin has tried to evaluate modern reason from the standpoint of the classical legacy of thought. Significant as his great contribution must be considered, it, however, assumes a restorative character not sufficiently qualified. Moreover, it fails to provide the new science of organizations and society with an operational and analytical expertise, required by the unprecedented historical conditions of our time. Another significant strand of criticism is represented by the so-called Frankfurt school which, I will show, is still fraught with modern historicist fallacies.

Chapter 2 is a critique of the contemporary model of social science from the standpoint of an alternative model which I call a substantive theory of human associated life. It draws upon Max Weber's distinction between Wertrationalität (value or substantive rationality) and Zweckrationalität (functional rationality) and Karl Polanyi's analysis of the market-centered society.

The third chapter conceptualizes the psychological syndrome inherent in the market-centered society and specifies its main features, namely, the fluidity of the self, perspectivism, formalism, and operationalism. It explains that as long as the citizens at large continue to succumb to the 


\section{xi Preface}

organized inducements, pressures, and influences which keep such a syndrome operative, there will exist, at best, little room for a revitalizing social transformation.

In the next chapter I argue that organization theory, as a disciplinary field, is losing sense of its specific objectives, by attempting to assimilate models and concepts extraneous to its proper domain. In substantiating this argument, I discuss instances of 'misplacement' of concepts exemplified by current issues in the field of organization theory. I conclude chapter 4 by articulating some basic permanent issues of the scientific study of formal organizations.

Chapter 5 presents the concept of cognitive politics. I show that cognitive politics is the most important hidden dimension of the psychology of the market-centered society. Organization theory has never reached the status of a scientific discipline because its proponents are unaware of such a dimension. Standard organization theory is pre-analytical in the sense that it accepts the state of human affairs in the market-centered society as a given, being unaware of a larger range of objective possibilities. The chapter focuses at length upon three unarticulated assumptions of current organization theory, namely, the identification of human nature with the behavioral syndrome inherent in the market-centered society, the definition of the person as a jobholder, and the identification of human communication with instrumental communication.

The sixth chapter lays bare the epistemological blindspots of extant organization theory and concludes by identifying the need for a new science of organizations based on the concept of social systems delimitation. My main critical contentions in this chapter are that current organization theory fails to distinguish systematically between substantive and instrumental rationality, and between the substantive and the formal meaning of the organization; it lacks a clear understanding of the role of symbolic interaction in interpersonal relations at large; and it relies on a mechanomorphic view of man's productive activity.

In chapter 7 I present a multicentric model of social systems analysis and organizational design which I call social systems delimitation. It depicts the market as a necessary, but limited social system, which is appropriately an enclave of society. It conceptualizes other social systems, as for instance isonomy and phenonomy, and describes essential dimensions of the multiple enclaves which are constitutive of the overall social fabric. This chapter is an introductory statement to what I call the paraeconomic paradigm.

The law of requisite adequacy is presented in chapter 8 as a funda- 
mental topic of the new science of organizations. According to this law a variety of social systems constitutes an essential qualification of any society, which is to be responsive to its members' basic needs of production and actualization. Moreover in this chapter I contend that each of these social systems prescribes design requisites of its own. The law of requisite adequacy is illustrated through an analysis of the technology, size, cognition, space, and time requisites of social systems.

In chapter 9 I discuss the policy implications of the paraeconomic paradigm. I contend that social systems delimitation is not only a theory bearing upon the micro-organizational level, but is also applicable at the macro-societal level. I illustrate this contention by discussing the processes of manpower and resource allocation from a delimitative perspective.

I conclude the book with a summary of the main tenets of the new science of organizations and trace the general direction of a research agenda which such a science implies.

The ten chapters of this book constitute an organic unit and must be read in the sequence they are presented, otherwise the reader will miss fundamental aspects of its conceptual thread. This is particularly true of the last chapter, where my policy and philosophical thrusts become evident. It cannot be understood if read as a discrete piece.

Chapters 4, 6, and 7 re-elaborate ideas and themes treated in articles which I had written earlier and were published in Public Administration Review and Administration and Society, as well as in Carl J. Bellone, ed., Organization Theory and the New Public Administration (Allyn and Bacon 1980). I appreciate the permission of these publishers for the use of these materials.

The search for a new science of organizations has been underway for some time. It has been a piecemeal endeavor undertaken painstakingly by a great number of scholars. This book takes advantage of much of their creative effort, and begins to mold it into an encompassing body of knowledge. 